\title{
CONSTRUCTION METHODS AND ARCHITECTURAL STRUCTURE OF MINARETS OF ANCIENT KHIVA
}

\section{Gavkhar Durdiyeva, Ergash Salaev, Kakhramon Saburov, Islombek Rustamov, Bekzod}

Khudayberganov, Adilbek Zargarov

Khorezm Mamun Academy, Regional branch of Academy of Sciences of the Republic of Uzbekistan, Tashkent, Uzbekistan.

E-mail: gavhar61@mail.ru

E-mail: saburov.kaxramon@mail.ru

E-mail: bek88_88_uz@mail.ru

\begin{abstract}
In this article, the methods of construction of minarets of Khiva, architectural composition, building materials, history of construction, devices of aboveground and underground parts, which are of special importance in the ancient Khorezm architecture, are described in scientific sequence and in-depth analysis for the first time. Much of this information is being inserted into scientific circulation for the first time.
\end{abstract}

Keywords:

architectural monument, minaret, basement, lantern, construction material, spiral, mezzanine, lantern, staircase, earthquake resistant.

Article Received: 18 October 2020, Revised: 3 November 2020, Accepted: 24 December 2020

\section{Introduction}

Precious architectural traditions of Uzbekistan embody all stages of the development of world cultural heritage, a variety of unique architectural works, and have left a significant mark on the architecture of unique buildings, such as minarets. Ancient eastern cities cannot be imagined without towers. In the words of the great commander Amir Temur: - "Whoever doubts our power, let him look at the buildings we have built." [2] Indeed, the restoration of the skyscrapers also demonstrated the position of that country, the power of its rulers. The minarets are also architectural monuments that make the oriental-style Nile-domed monuments even more glorious and luxurious.

Minarets are considered the highest constructions of the Middle Ages. The word 'Minaret' is derived from an Arabic word and means a place where the azan is told. Building minarets widely spread in Central Asia after the Arab invasion. But until then there had been minarets as well. Abu Rahyan Beruniy gives information about the minarets of 25 meters of Afrighids in his work "Asar ul baqia".

Minarets had three main functions [4]:
1) to target

2) observation, control

3) telling azan

Today, the question of how are the styles of ancient constructions of Khiva, history and architecture of minarets in Khiva is one of the questions which attracts everyone. An important part of the restoration practice of minarets in the architectural and construction direction of the Khorezmshah Empire was marked by its unique solutions, artistic and compositional features and played a special role in the development of Khiva architecture. The minarets of Khiva are similar in construction to the Old Urgench tower. Minarets of Khiva differ from other towers with their dynamics, contractions of top parts and decorations. The towers are built in a conical shape narrowing upwards. There is a distinctive fonus-shaped dome on top part. There were some holes on the minaret so that the light came into for illumination. At the top there are windows, on which are mounted grating bars. The height and decoration are different. Some are decorated with tiles. It was possible to ascend to the top through the spiral staircase in the minaret.

Materials and methods 
Here, domed public buildings, flat-roofed dwellings, and high-rise towers are intertwined [5]. There are many architectural monuments in Khiva and they were preserved well. There are more than 16 minarets in Khiva, they are either big or small. A number of towers of Ichan Kala, located along the main "Khan Street", beautified ancient

Khiva (figure

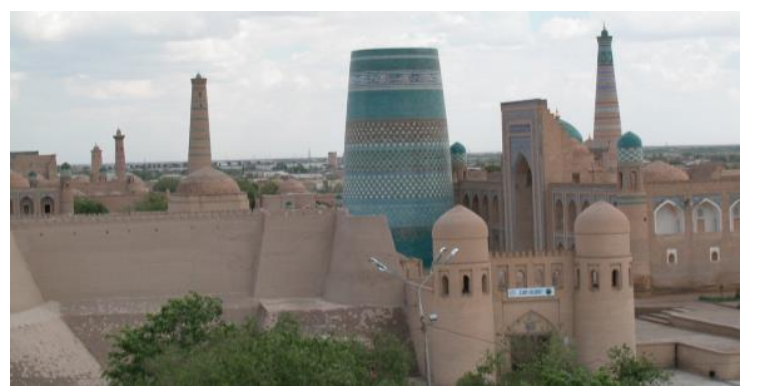

\section{Figure 2. General view of the minarets in Ichan Kala}

In this article, for the first time, constructive methods of the minarets which are the important constructions of Khiva, architectural composition, building materials, history of foundation, surface and subterranean devices are scientifically covered in a deep analysis. Much of this information has been put into scientific circulation for the first time.

Due to the fact that the restored minarets in Khiva are in the shape of circular vertical structure, their architectural composition narrows from the base to the top. Constructing the minarets or other buildings required using the phenomenal secrets of that field. Furthermore, several factors such as wind flow, seismic vibration, the structure of the ground layer are taken into consideration in the construction of minarets [2].

The structure of the site was studied before the construction of the tower. The towers of each region are built in a unique way. According to the requirements of the operational process of the ancient towers, there was a need to make stairs and lanterns in the building. Stairs are made in the form of a screw by approaching the outer wall at a minimum distance around the core. Inside the towers - from the bottom to the top (spiral) stairs and lanterns for light to enter [1].

Saidniyaz Sholikorboy complex was built in 1835-1842 under the auspices of Saidniyaz Sholikorboy, a great merchant who was one of the dearest and greatest people of Khiva. Ollokulikhan who was known as an architect khan, in his 17 years of period, attempted to create several architectural monuments and to stabilize them as well.

Foreign guests, visitors and tourists are always impressed not only about architects' creative skills but also regarding their knowledge of mathematics, geometry. Moreover the owners of these workmanships also created a beautiful kind of art based on geometric proportions with the only mud or burnt bricks (figure 2)

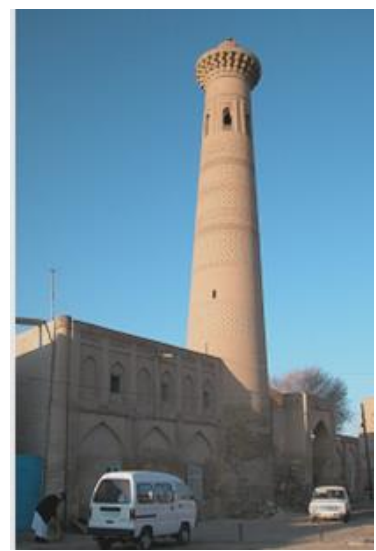

Figure 2. Minaret was damaged due to Minaret the man-made effects 


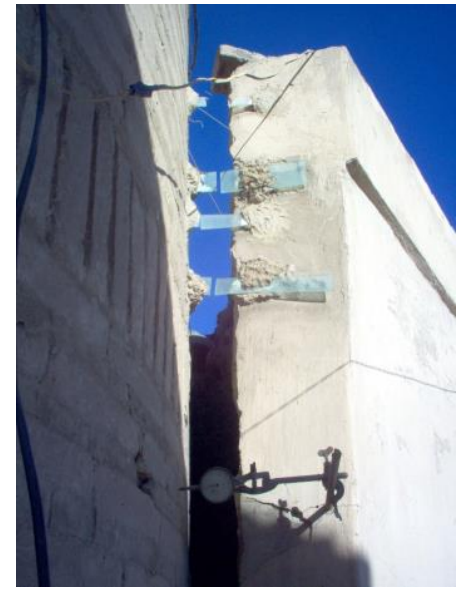

Figure 3. Deformation of (Glass indicators)

\section{Methodology}

A monitoring was held in order identify the technic condition of the minaret of the mosque Saidniyoz Sholikorboy, its foundation and basis were researched. According to the results, it was determined that the technic condition of the mosque, where the people still use to pray on Friday, is unsatisfactory and the minaret leaned to one side (because of the rise of groundwater in this area and failure of drainage system).

The height of the minaret is 29.5 meters and it has been built from burnt bricks. The inner walls of the tower thin up to the top just like the outer walls. It was identified that the minaret leaned to southern-west side for 1.07 meters, and this is six times more than allowed by regulations. At the same time, it was noted that due to the high moisture content of the soil in this area, groundwater is located only $70 \mathrm{~cm}-1.0 \mathrm{~m}$ above the soil level.

In order to prevent the negative situations in the above, several engineering and practical events were carried out. Otherwise, it is possible that the minaret will not be able withstand a 4-5 magnitude earthquake since strength of the basement reduced, or after 10-20 years, even under the influence of strong winds, the tower may collapse ( $2^{\text {nd }}$ and $3^{\text {rd }}$ figures).

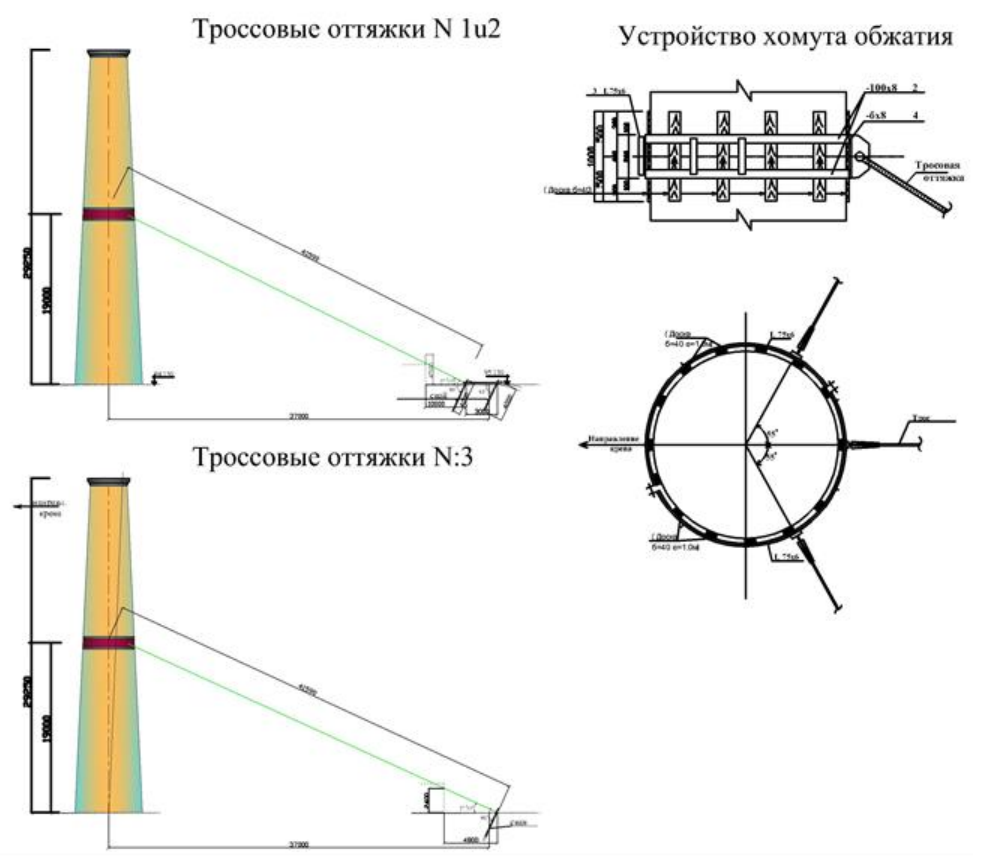

Figure 4. Elements of 'iron belt' project about construction of the minaret Saidniyoz Sholikorboy 
According to the research, the depth of the basement of the tower is 3.5 meters. The basement of the minaret has been built with complex methods, materials are also made in specific technological processes and the clay which was in $20 \mathrm{~cm}$ thick and laid on the ground of the basement was made of a mixture of alabaster-mud and reed ash. Muslim (quadratic) bricks were laid on the clay, a $30 \mathrm{~cm}$ 'platform' was done throughout the perimeter, then the foundation was laid and it contains 4 levels.

We now analyze the performance features of the foundation and basement as follows: Mud

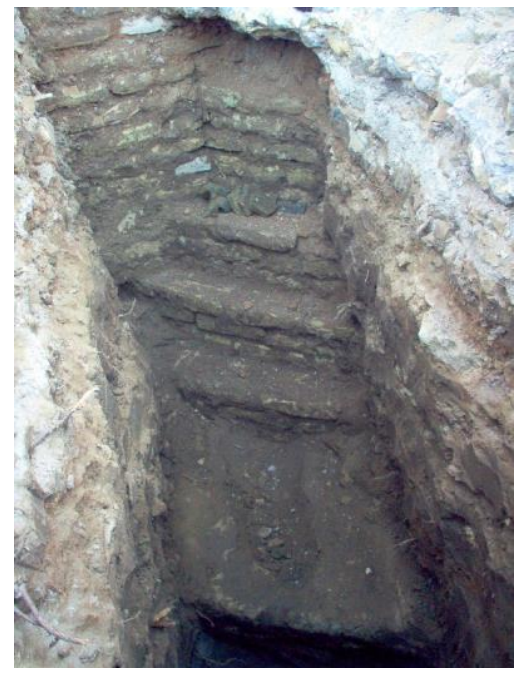

a covering makes the floor smooth and it provides both seismic isolation and waterproofing. The 'platform' stops the wave of earthquake from the ground. Leveled basement helps the minaret to stand against several negative forces (figure 5, a). Conclusion

While carrying out the research it was attentive that because we addressed the cultural heritage department and government's official employees, the damaged canalization system was removed in that area, iron bars were placed on both sides of the tower to reduce man-made (transport) impacts.

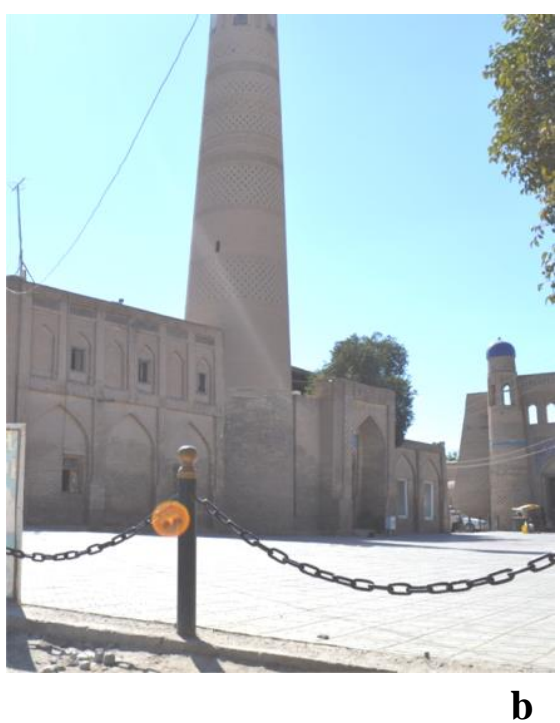

Figure 5. Basement of the minaret (a), Addressed to the department (Iron bars were placed) the deformation was stopped.

According to the research, it can be said that ancient Khorezm architects and constructors were quite good at geometry, mathematics and they could correctly organize technological issues and constructions. It is clear from history that because our ancestors were creative thinkers about their fields, they transferred their thoughts into practice gradually, which means they could use them in constructions.

Moreover, because the architects knew perfectly the mysteries of scale in the field of architecture, most of the minarets still exist and they have not lost yet their stabilities and earthquake resistance. Although the minaret Saidniyoz Sholikorboy has undergone many earthquakes, man-made impacts since its foundation, it has been attracting the attention of fans for many centuries, as a perfect creative product of great master-architects.

To conclude, its requirement of current time to comprehensively research and preserve the unique heritage of Khiva master architects and their earthquake resistant methods used in construction of towers.

\section{References}

[1] Azimov I. Khiva minoralari. 'Sanat'. 2002. № 7

[2] Axmedov M.Q. O'rta Osiyo me 'morchiligi tarixi. T.2015. 212 p.

[3] Bulatova V.A., Notkin I.I. Xivaning arxitektura yodgorliklari. T.1963.48 p 
[4] Nazilov Dodo. Minora ramzi (Habits, rules and symbolic expressions). T.2006. 123 p.

[5] Khiva ming gumbaz shahri. Tashkent, 1997, 68 p. 88 p.

[6] Zohidov P.SH. Xivinskie ugrozy. Stroitelstvo i arxitektura Uzbekistana. 1983. № 10. P 17-25.

[7] Qodirova T.F. Sanat, arxitektura va shaharsozlik tarixi. Oliy o`quv yurtlari uchun darslik. - Toshkent: 'cho'lpon' NMIU. - 2012. - p. 4-97.

[8] Mannoev S.B. O'zbekiston zamonaviy shaharsozligida me`moriy ansambl va komplekslar. Samarqand. 2014. Avtoreferat.

[9] Mankovskaya L.Yu. Xiva. Muzey pod otkrytym nebom. T.1982. p 18.

[10] Masson M.E. Padayushiy minaret. (From the memoirs of a participant in the maintenance and rehabilitation of the "falling" northeastern minaret of the Ulugbek madrasah(1918-1932yy.). t.1969. p 67.

[11] Durdieva G.S. Xivadagi 'Islomxo`ja' minorasining balandligini aniqlashdagi geodezik o'lchash ishlari. 'Problemy arxitektury I stroitelstva', Samarqand, 2011. № 2.

[12] Notkin I.I. ansambl u vostochnyx vorot Ichan-Kaly v gorode Xive. Rukopis. 1957 y. arxiv Glav NPU obyektov kulturnovo naslediya.

[13] Pribytkova A.M. konstruktivnie osobennosti sredneaziatskix minaretov $\mathrm{X}$ XII cc. 'Arxitekturnoe naslediya'. M.1964. № 17.

[14] Pugachenkova G.A. Arxitekturnie ruiny: restavratsiya ili konservatsiya. Stroitelstvo I arxitektura Uzbekistana. 1995. №1-2. P. 37-39.

[15] O’rolov A., Qodirova T.F. 'Orta Osiyo arxitektura yodgorliklarining tipologik asoslari'. T.2012. p 51. 